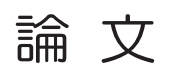

Original Paper

\title{
GPS による長大斜面の変位計測の精度について*
}

\author{
松 田 浩 朗 ${ }^{1}$ 清 水 則 - $^{2}$ \\ 川 畑 一 洋 ${ }^{4}$ 千 葉 敏 博 $^{4}$ \\ \begin{tabular}{lll} 
吉 & 富 & 功 $^{3}$ \\
頓 所 & 幹 \\
\hline
\end{tabular}
}

\section{Accuracy of Displacement Monitoring of Large Slopes by Using GPS}

by Hiroaki MATSUDA ${ }^{\mathrm{a}}$, Norikazu SHIMIZU ${ }^{\mathrm{b}}$, Isao YOSHITOMI ${ }^{\mathrm{c}}$,

Kazuhiro KAWAHATA ${ }^{\mathrm{d}}$, Toshihiro CHIBA $^{\mathrm{d}}$ and Motohiro TONSYO ${ }^{\mathrm{d}}$

a. Graduate School of Science and Engineering, Yamaguchi University

b. Faculty of Engineering, Yamaguchi University, 2-16-1, Tokiwadai, Ube-shi, Yamaguchi, 755-8611,

Japan (Corresponding author : E-mail shimizu@rock.civil.yamaguchi-u.ac.jp)

c. SYUHO MINING CO., LTD

d. Study Committee on Slope Stability and Environmental Preservation in Chichibu Area (Zanpeki Kenkyukai)

A displacement monitoring system has been developed using the Global Positioning System. It has been applied to large slopes of limestone quarries, landslide slopes to monitor the slope stability. The system can measure the three dimensional displacements continuously and automatically. The accuracy of measurements is beyond the standard one of the GPS by applying the trend model to the measurement results.

This paper focuses on two topics. One is long-term continuous monitoring and the other is monitoring under the condition of the high height difference between the measurement points. The errors and the periodic characteristics of the measurement results are discussed through case studies. And then the standard deviation is shown in the relation to the distance and the height difference between measurement points. It will be available for planning the displacement measurement using GPS.

KEY WORDS : GPS, Displacement Measurements, Long-term Monitoring, Large Slopes, Accuracy

\section{1.は じめに}

我が国の主要な石灰石鉱山は露天採掘を採用しており，掘削後 には長大な斜面が生まれる。このような長大斜面の安全監視は, 採掘作業環境の安全性のみならず, 周辺の住民の安全確保, また, 周辺環境の保全の立場から重要である。斜面の安全監視を目的と した計測は，一般に変位計測が行われることが多く，実際，石灰 石露天採掘鉱山の斜面において地表面変位や地中変位が計測され ている ${ }^{1-4)}$

筆者らは, GPS(Global Positioning System : 人工衛星測量システ ム）を用いた変位計測システムを共同開発し ${ }^{5-7)}$, さらに, 本シ ステムから得られる計測結果に対してトレンドモデル ${ }^{8)}$ による平 滑化を行うことで, 従来の GPS による変位計測の精度を上回る結 果を得ることを明らかにした ${ }^{9,10)}$ 。そして，実測を通して斜面の 変位計測に対する実用性を示してきた ${ }^{10,11)}$ 。

一方，鉱山斜面の安全監視においては，システムの長期計測に 対する安定性が必要となる。さらに, GPS による測量においては, 計測点間の基線長および高低差が大きくなると計測結果の標準偏 差が大きくなることが指摘されている ${ }^{12,13)}$ 。このため, 本システ ムの長大斜面の安全監視における適用性および限界をより明確に するために，長期安定性と計測点間の基線長と高低差に対する計

* 2002 年 10 月 15 日受付 2003 年 4 月 14 日受理

1. 山口大学大学院生 理工学研究科 環境共生工学専攻 博士後期課程

2. 普通会員 博士 (工学) 山口大学教授 工学部 社会建設工学科

3. 普通会員 秋芳鉱業 (株) 取締役社長

4. 普通会員 研究当時 秩父地区残壁研究会

[ 著者連絡先 ] E-mail : shimizu@rock.civil.yamaguchi-u.ac.jp (山口大・清水 )

キーワード: GPS, 変位計測, 長期モニタリング, 長大斜面, 計測精度
測精度を把握することが重要である。

本研究では, 筆者らのこれまでの GPS 変位計測システムの適用 結果に基づき，1）長期間の連続計測の安定性，および，2）計測点 間の高低差の大きい条件下における計測に対する標準偏差, につ いて検討する。

\section{2. 本研究で用いる GPS 変位計測システムと計測結果の 処理法の概要}

$2 \cdot 1$ GPS 変位計測システム

筆者らが利用しているシステムは, キネマティック方式に基づき オンラインでデータ処理するリアルタイム計測システム ${ }^{5}$ ( 図 1(a)。 以下, オンラインシステムと呼ぶ), および, スタティック方式に 基づきオフラインでデータを処理するシステム ${ }^{14)}$ (図 1(b)。以下, オフラインシステムと呼ぶ ) である。いずれも, 長期間の連続計 測を目的としている。

オンラインシステムは，アンテナと受信機を基準点および計測 点に設置し, それらを電源供給も兼初る同軸ケーブルによって パーソナルコンピュータに接続する。人工衛星から受信した信号 とデータはケーブルを通してコンピュータに送られ, 結果は直ち に表示される。なお，この間はすべて自動処理される 5)。このシ ステムは, 露天掘り鉱山斜面 ${ }^{7)}$ および地すべり斜面 ${ }^{11)}$ に適用さ れている。

一方, オフラインシステムでは, 基準点と各計測点にアンテナ と受信機をそれぞれ設置し, 電源はバッテリーやソーラーパネル, または家庭用電源によって供給する。人工衛星から受信した信号 とデータは受信機内のメモリ，またはメモリカードなどの記録媒 


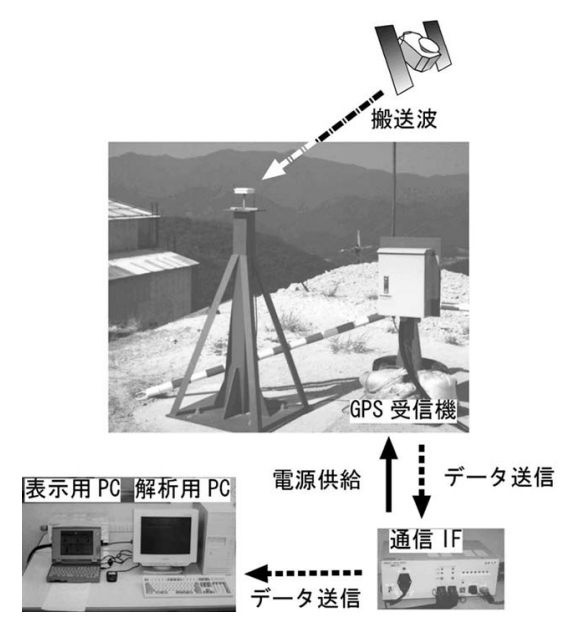

(a) オンラインシステム

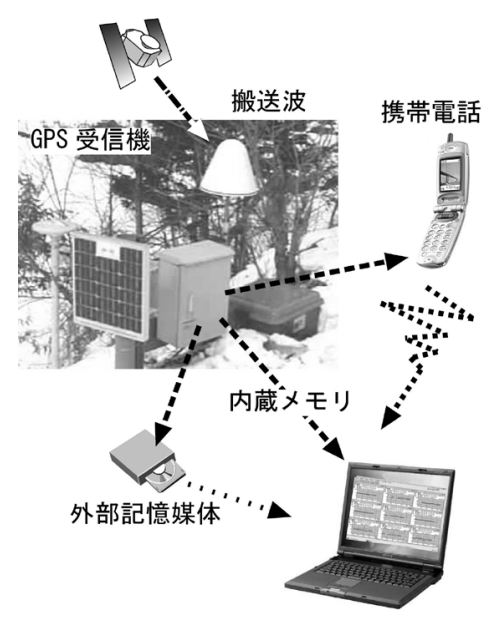

(b) オフラインシステム

図 1 GPS 変位計測システム

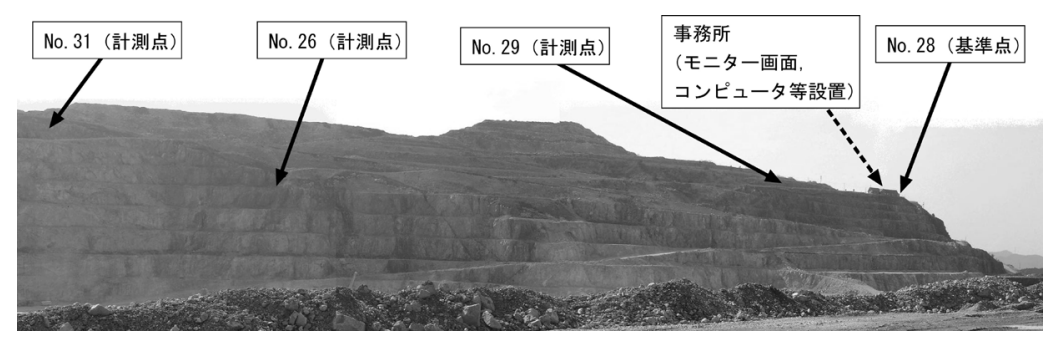

図 2 秋芳鉱山における受信機の設置状況

体にいったん保存し, それらをコンピュータにダウンロードして, スタティック方式で解析して変位を得る。受信データのダウン ロードは, 直接受信機とパーソナルコンピュータを RS-232C で接 続する方法と, 電話回線 ( 携帯電話) などを用いる方法がある。こ のシステムは, 地すべり斜面 ${ }^{14)}$ や道路切り取り斜面 ${ }^{15)}$ に適用し ている。

本研究では，3. においてはオンラインシステムを，4. におい てはオフラインシステムを用いる。

\section{$2 \cdot 2$ トレンドモデルによる計測結果の処理}

斜面の安全監視を目的とした変位計測に適用寸る場合, GPS の 一般的な精度 (水平方向 $5 \mathrm{~mm}+1 \mathrm{ppm} \times$ 基線長 $(\mathrm{km})$, 高さ方向 10 $\mathrm{mm}+2 \mathrm{ppm} \times$ 基線長 $(\mathrm{km}))^{12,13)}$ よりも高い精度が要求される。そ こで，筆者らは時間方向に連続的に計測した変位に対して，平滑 化手法の一つであるトレンドモデル ${ }^{8)}$ を適用することを提案した $9,10)$

トレンドモデルとは, 多項式回帰モデルに確率構造を導入した トレンド成分モデルをシステム方程式とし，観測方程式とあわせ て次のように連立させるものである ${ }^{8)}$ 。

$$
\begin{array}{ll}
\Delta^{k} u_{n}=v_{n} & \text { (システム方程式) } \\
y_{n}=u_{n}+w_{n} & \text { (観測方程式) }
\end{array}
$$

ここで，上式において $u_{n}$ は経時的に推移する真の変位，および， $y_{n}$ は実際に計測される変位である。また, $w_{n}$ は観測ノイズ $($ 計測 誤差 : 平均值 0 , 標準偏差 $\sigma$ の正規分布に従うと仮定), および $v_{n}$ はシステムノイズ (モデル誤差 : 平均值 0 , 標準偏差 $\tau$ の正規分布 に従うと仮定 ) である。 $\Delta$ は時間差分演算子であり, 添字 $k$ は差分 の階数を意味する。

式 (1) および式 (2)で表したトレンドモデルにおいては, 真の変 位 $u_{n}$, 確率差分方程式の階数 $k$ ( モデル次数と呼ぶ $)$, 計測誤差を
表すパラメータ $\sigma^{2}$ ( 観測ノイズの分散 ), モデル誤差を表すパラ メータ $\tau^{2}$ (システムノイズの分散) が未知パラメータである。これ らのパラメータは, カルマンフィルタのアルゴリズムを適用し,

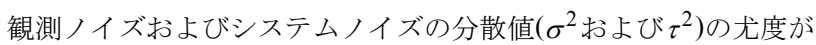
最大となるように推定する。さらに, モデル次数 $k$ は AIC( 赤池情 報量基準 ) が最小となるように推定する ${ }^{8,9)}$

この方法によって, 突発性変位やクリープ変位など様々なパ ターンの変位の平滑化と真の值の推定が精度良く行われることが 示されている ${ }^{9,10)}$ 。

\section{3. 長期間連続計測}

石灰石露天採掘鉱山 ( 山口県秋芳鉱山 ) において, 1995 年以来, オンラインシステムを用いて, 計測実験 (1995-1996) および, 基準 点付近に計測点を設置した試験運用 $(1997 \sim 1999)^{6,7)}$ を実施し, その後, 1999 年 12 月から本運用として計測点を掘削工事斜面上 部に移動し, 日常の安全監視を行っている ${ }^{16)}$ 。GPS アンテナは図 2 に示すように斜面頂部に 4 ヶ所設置し, 内 1 点を基準点 (No.28) としている。なお, 基準点から計測点の基線長は, それぞれ, No.29 が 145 m, No.26 が 598 m, No.31 が 711 m である。システムを制 御しデータを解析するパソコン，および，リアルタイムに計測結 果を表示するモニタ画面は, 基準点付近の事務所に設置している。

本鉱山の採掘領域は, 長さ $1,200 \mathrm{~m}$, 幅 $600 \mathrm{~m}$ で, 本運用を始め てから計測点 No.26 および No.31 直下の斜面について, ベンチ 1 段 $(15 \mathrm{~m})$ が掘削された。現在の斜面高さは $135 \mathrm{~m}$ であり, 計測点 No.31 は掘削レベルから高さ $115 \mathrm{~m}$ に位置する。

\section{$3 \cdot 1$ 連続計測結果}

図 3 に計測点 No.31 の計測結果 ( 緯度, 経度および高さ方向の 変位: 図中○印 ) を示す。図に示した計測結果は本格運用後の 1999 


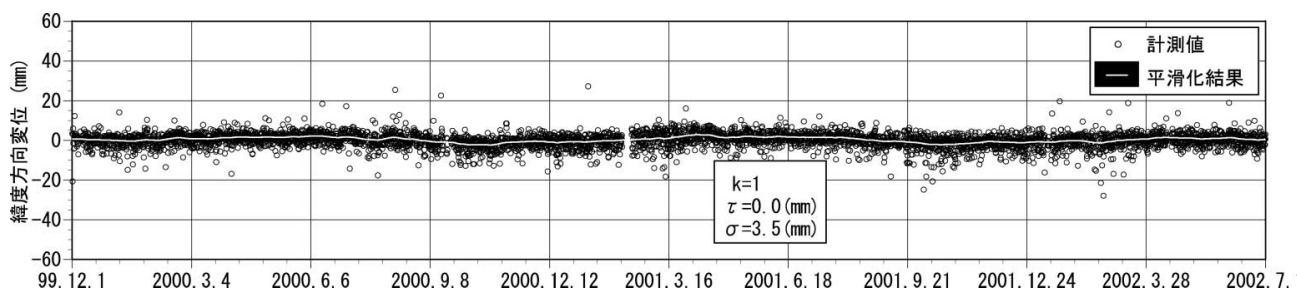

(a) 緯度方向

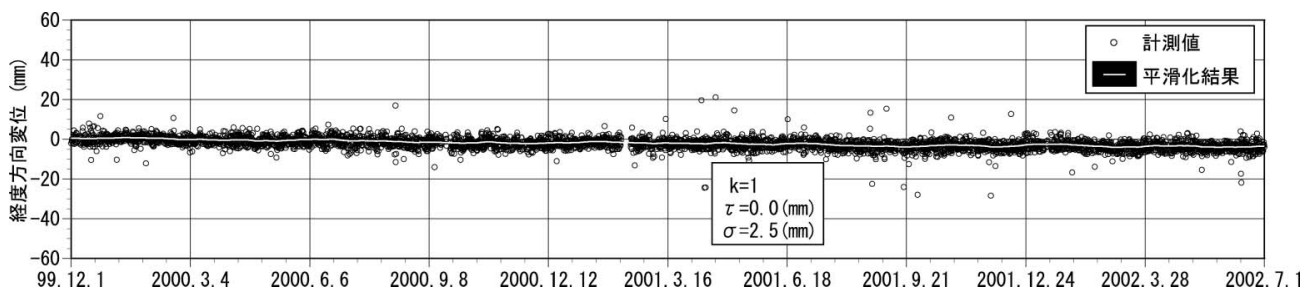

(b) 経度方向

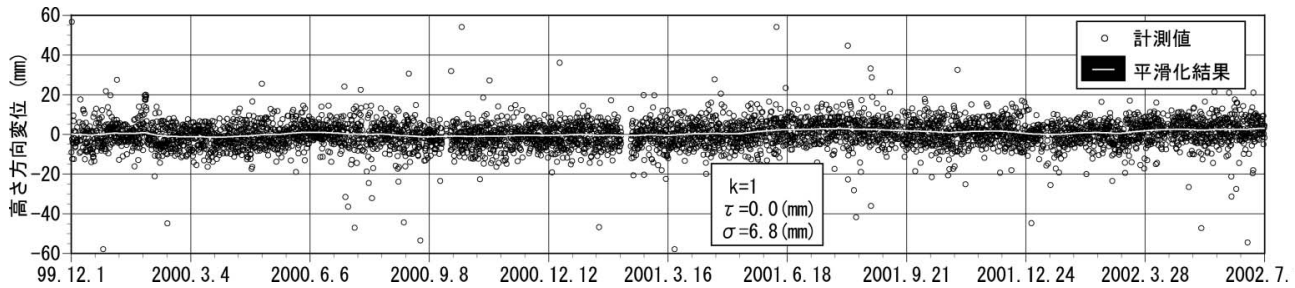

(c) 高さ方向

図 3 計測結果 (計測時間間隔 4 時間 )

年 12 月から 2002 年 6 月末までである。なお, GPS の人工衛星か らのデータ取得は 20 秒間隔, また, 計測期間中は 1 時間連続計測 したデータを用いて毎時キネマティック方式で解析している。図 3 には, そのようにして求めた毎時のデータを 4 時間間隔でプロッ トしている。また，同図にはトレンドモデルによる平滑化結果を 実線 (白抜き) で示している。図の中の $k, \tau$ および $\sigma$ は, $2 \cdot 2$ で説 明したトレンドモデルのパラメータである。

図 3 から, 計測結果は水平方向に対して $\pm 5 \sim 10 \mathrm{~mm}$ 程度, 高 さ方向に対しては土10〜 $20 \mathrm{~mm}$ 程度の範囲におおむね収まってい る。トレンドモデルによって推定した標準偏差 $\sigma$ は緯度, 経度, 高 さ方向に対して，それぞれ $3.5 \mathrm{~mm}, 2.5 \mathrm{~mm}, 6.8 \mathrm{~mm}$ である。計測 は 2.5 年 (試験運用を含めると 4.5 年) にわたり長期的に安定して 行われていることがわかる。また，上に述べたように，計測期間 中, No.26 およびNo.31 の直下の斜面で $15 \mathrm{~m}$ 掘削された。計測結 果から, 計測精度の範囲内において, 斜面に掘削による変位は生 じていないものと判断できる。

次に，計測結果について月別の標準偏差を図 4 に示す。同図に は, 計測点 No29, No.26, No31 に対する值を年別に示した。緯 度, 経度, 高さのいずれの方向も, 標準偏差は年間を通して大き な変化はなく，同じ精度で計測されていると思われる。

\section{$3 \cdot 2$ 周期性}

計測結果の周期性を調べる目的で, 1 時間ごとの計測結果につ いてフーリエ・スペクトルを求めた。図 5 にそれぞれの方向のフー リエ・スペクトルを示す。図 5 から, いずれの方向の計測結果と も 12 時間，および，24 時間にピークがあり，周期性がみられる。 このような周期性は, 本計測結果だけでなく, 他の斜面における 実測例においても同様に見られる ${ }^{17)}$ 。

12 時間の周期性については, GPS 衛星は 11 時間 58 分 ${ }^{12,13)}$ で 地球を周回しており, 約 12 時間ごとに同じ衛星配置となることが 原因と考えられる。すなわち, 衛星の高度, 相対的な位置関係に

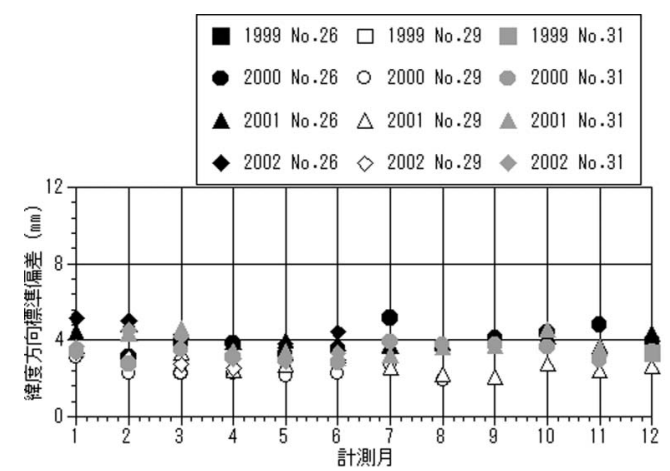

(a) 緯度方向

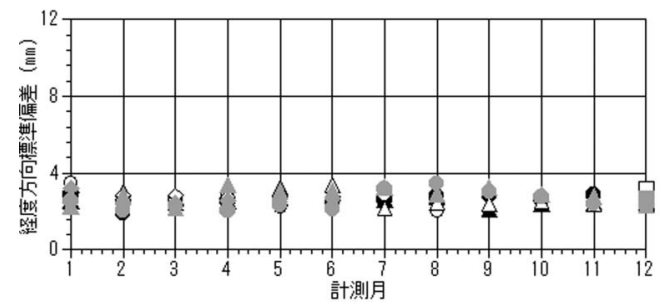

(b) 経度方向

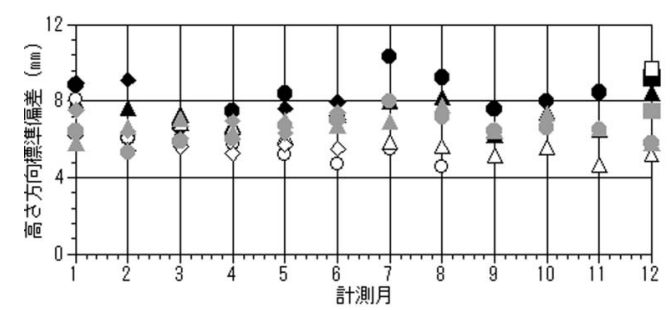

(c) 高さ方向

図 4 計測月別標準偏差 


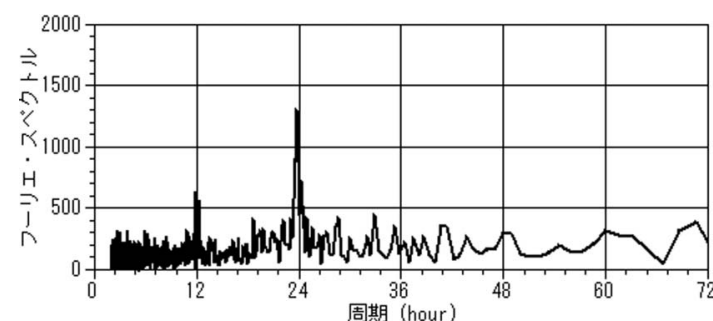

(a) 緯度方向

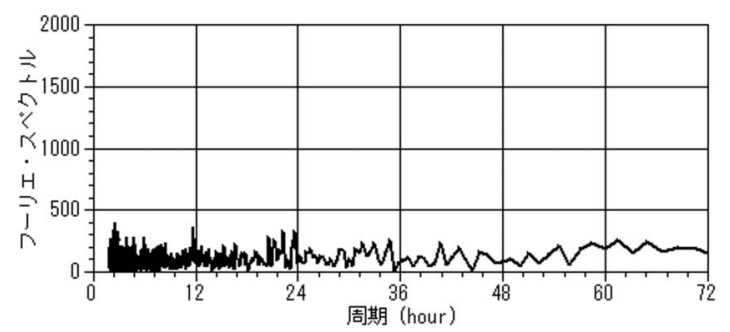

(b) 経度方向

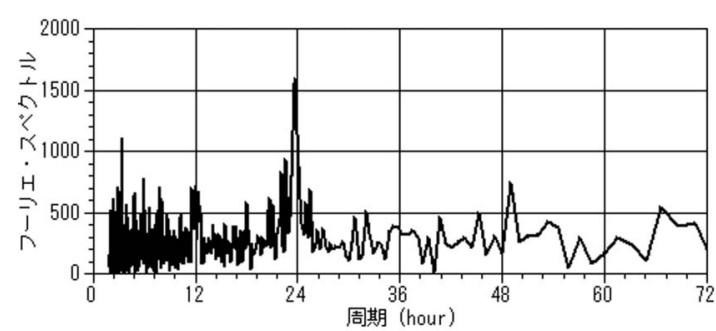

(c) 高さ方向

図 5 フーリェ・スペクトル

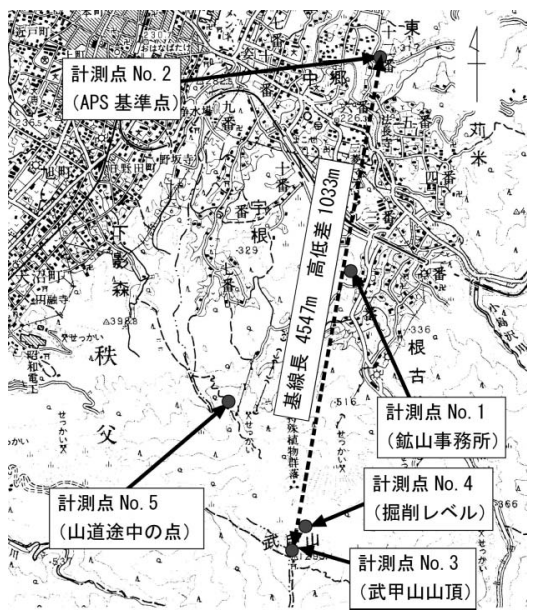

図 7 現場平面図
計測精度が依存することが知られている ${ }^{12,13)}$ 。一方, 24 時間の周 期性については，気温等の気象条件の日変動と関係があると思わ れる。もし, 計測点間の気象条件が同一である場合, スタティッ ク方式やキネマティック方式による相対測位法では, それらの影 響を除去できるアルゴリズムとなっている。しかし実際のところ, 両計測点における気象条件の差や, 気象条件の影響を補正するモ デルが確立されていないことから, 完全には影響を取り除くこと は難しい12,13)。

これらの周期性が，斜面の実際の変位と直接関係がない場合は (たとえば, 温度変化によって生じる変位などが十分小さいと考え られる場合), 周期性の部分と実際の変位の部分を分離して, 周期 性を除去寸る必要がある。しかしながら，このような周期性を除 去寸る一般的な方法は今のところなく, 気象条件や衛星配置を考 慮した方法の開発は課題である。

図 6 に，1 時間ごとの緯度方向変位の計測結果にトレンドモデ ルを適用して平滑化した結果を示す。 4 時間ごとの計測結果を平 滑化した図 3(a) と比べると, 平滑化結果は周期的に波打つ結果と なっている。この波の周期はおおよそ 24 時間であり, 図 5(a) に示 される計測結果の持つ本来の周期性が， 1 時間ごとの計測結果の 平滑化結果に強く反映されている。一方, 4 時間ごとの計測結果 の平滑化結果には 24 時間の顕著な周期性は見られず (図 3), 長期 間の変位のトレンドをみるには都合が良いように思われる。この ように, 著者らは, 1 時間ごとの計測結果をすべて用いないで, あ る時間間隔で計測結果をピックアップして平滑化し，24 時間前後 の顕著な周期性を除去している。

\section{4. 計測点間の高低差の大きい条件下における計測}

計測点間の基線長や高低差が大きい場合, 両計測点の気象条件 が大きく異なることがあると考えられる。長基線長に対しては, これまで多くの実測結果があるが, 高低差が大きい場合の実測結 果は，著者の知る限りあまり公表されていないようである。

そこで, 変位計測結果におよぼす高低差の影響を調査する目的 で, 長大露天掘り斜面 ( 埼玉県武甲山 ) において, 約 1 週間の実 験を行った。図 7 に実験領域の平面図と計測点の配置を示す。設 置した基準点および計測点は, 武甲山の麓にある鉱山事務所 ( 計 測点 No.1), 光波測距儀を用いた変位監視システム (APS $)^{2)}$ の基準 点 ( 計測点 No.2), 武甲山山頂の APS 計測点 ( 計測点 No.3), 掘削 レベルの 1 点 ( 計測点 No.4), ならびに鉱山事務所から掘削レベル までの山道途中の点 ( 計測点 No.5) の合計 5 点である。計測点間 の最大の基線長, および高低差は, No.2 - No.3 に対して, それ ぞれ 4,547 m, および, $1,033 \mathrm{~m}$ である。変位計測は, オフライン システムを用いて行い, 以下の結果は 1 時間の計測データ ( 人工 衛星からのデータ取得間隔 30 秒) をスタティック方式で解析した ものである。

図 8 に計測点 No.1 - No.2( 鉱山事務所-APS 基準点 : 計測点 間基線長 $1,956 \mathrm{~m}$, 高低差 $25 \mathrm{~m}$ ) の計測結果を示す。計測結果の標 準偏差は緯度，経度，高さ方向に対して，それぞれ $4.4 \mathrm{~mm}, 2.4$ $\mathrm{mm}, 6.1 \mathrm{~mm}$ である。次に, 図 9 に計測点 No.1 - No.3( 鉱山事務

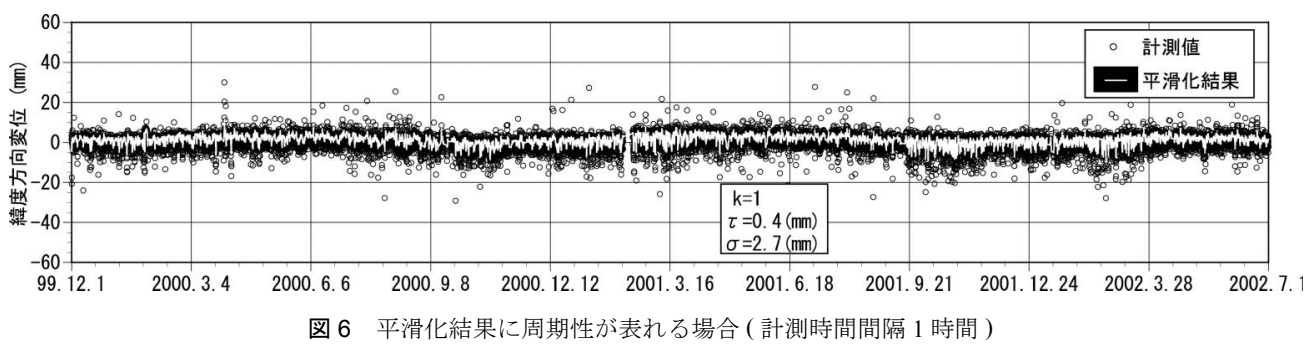




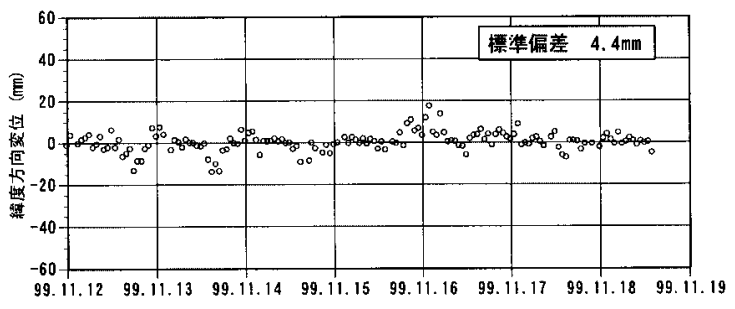

(a) 緯度方向

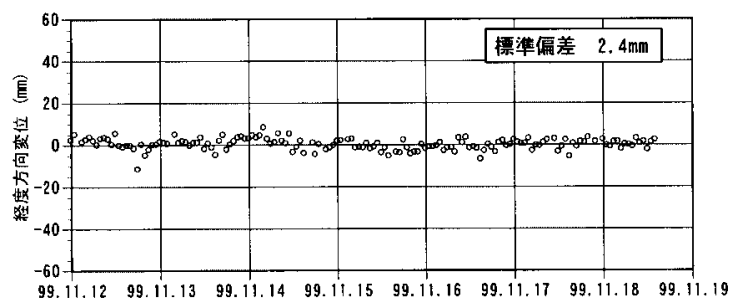

(b) 経度方向

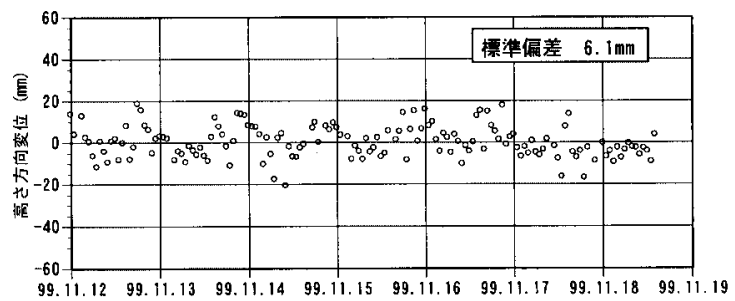

(c) 高さ方向

図 8 計測結果 $($ No.1 - No.2 : 基線長 $1,956 \mathrm{~m}$ ，高低差 $25 \mathrm{~m}$ )

所一武甲山山頂 ) の計測結果を示す。計測点間の基線長は $2,672 \mathrm{~m}$

で，No.1 - No.2 間の基線長とほぼ同じであるが，高低差は 1,008 $\mathrm{m}$ である。緯度, 経度方向の計測結果の標準偏差は, それぞれ 4.5 $\mathrm{mm}, 2.6 \mathrm{~mm}$ であり, No.1 - No.2 間の結果とほぼ同じであるが, 高さ方向の計測結果の標準偏差は $26.5 \mathrm{~mm}$ と非常に大きな值と なっている。図 9 からわかるように, 11 月 $15 \sim 16$ 日の間に, 高 さ方向の計測結果に $60 \mathrm{~mm}$ を超える変動が確認できる。

図 10 に計測点 No.4 - No.3( 掘削レベルー武甲山山頂 : 計測点 間基線長 $482 \mathrm{~m}$, 高低差 $263 \mathrm{~m}$ ) の計測結果を示す。計測結果の標 準偏差は緯度, 経度, 高さ方向それぞれ $2.1 \mathrm{~mm}, 1.8 \mathrm{~mm}, 9.1 \mathrm{~mm}$ である。この結果においても, 高さ方向の標準偏差は高低差の少 ない場合に比べて大きく, また, 11 月 15 日を境に $10 \mathrm{~mm}$ 程度の 変動がみられる。

GPS による計測では一般に, 計測点間の基線長に比例し計測結 果の標準偏差が大きくなることが知られているが ${ }^{12,13)}$, 以上の結 果からは基線長が同程度でも, 高低差が大きいと標準偏差も大き くなるようである。特に, 図 8 および図 9 に示した No.1 - No.2 と No.1 - No.3 間の計測結果においては, 緯度・経度方向の計測 結果の標準偏差はほぼ同じ值であるが，高さ方向の計測結果の標 準偏差には大きな差がある。これは, No.1 - No.2 と No.1 - No.3 の計測条件において最も大きな相違点の高低差 (約 $1,000 \mathrm{~m}$ ) が原 因と推察される。また，No.4 - No.3 間の計測においては，基線 長はNo.1 - No.2 に比べてかなり短く, 緯度・経度方向の標準偏 差もまた No.1 - No.2 に比べて小さいが, 高さ方向の標準偏差は むしろ大きい。図 10 に示される緯度・経度方向の標準偏差は, こ れまで筆者らが実施してきた高低差の少ない場合の計測結果と同 じ程度であることを考慮すると, 高さ方向の標準偏差が大きい原 因は，やはり高低差にあるように思われる。

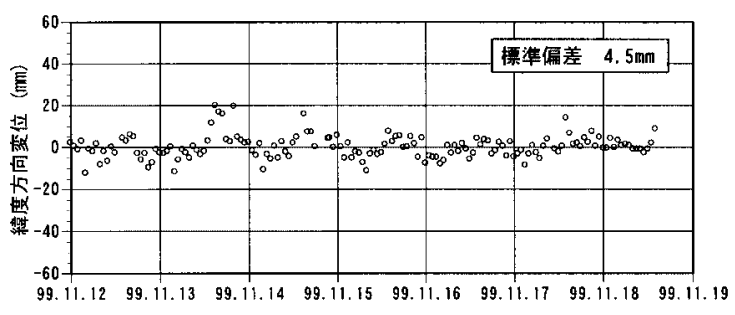

(a) 緯度方向

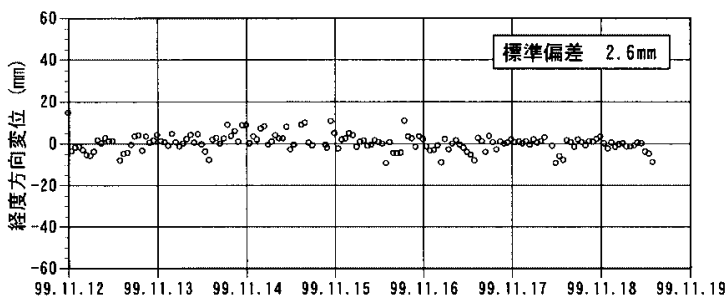

(b) 経度方向

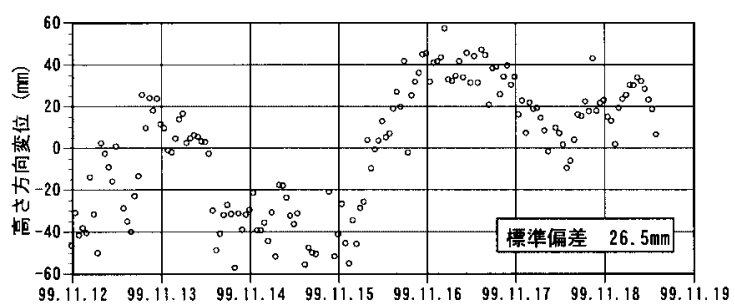

(c) 高さ方向

図 9 計測結果 $($ No.1 - No.3 : 基線長 2,672 m, 高低差 1,008m)

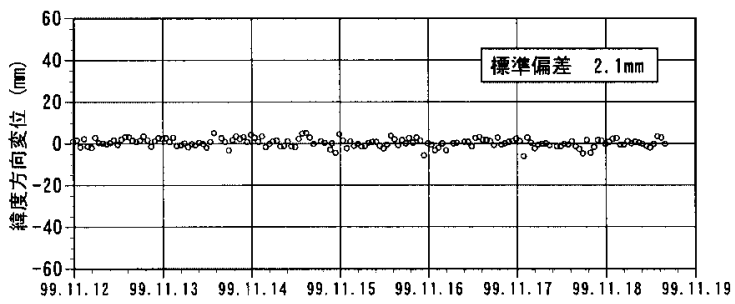

(a) 緯度方向

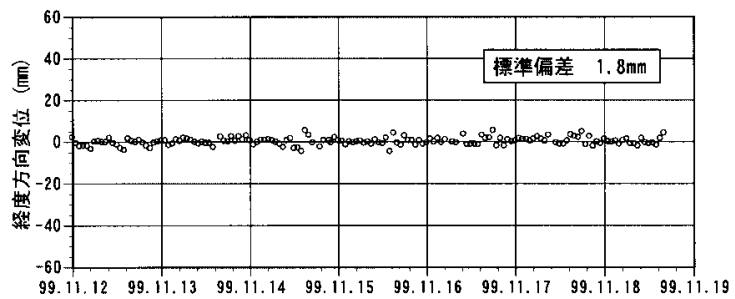

(b) 経度方向

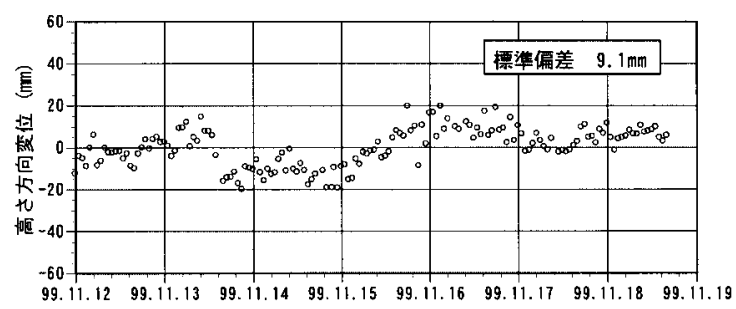

(c) 高さ方向

図 10 計測結果 (No.4 - No.3 : 基線長 $482 \mathrm{~m}$ ，高低差 $263 \mathrm{~m}$ ) 


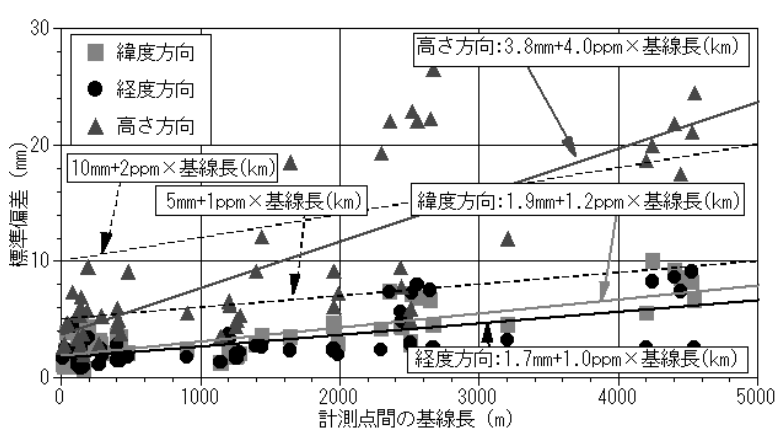

図 11 計測点間の基線長に対する標準偏差

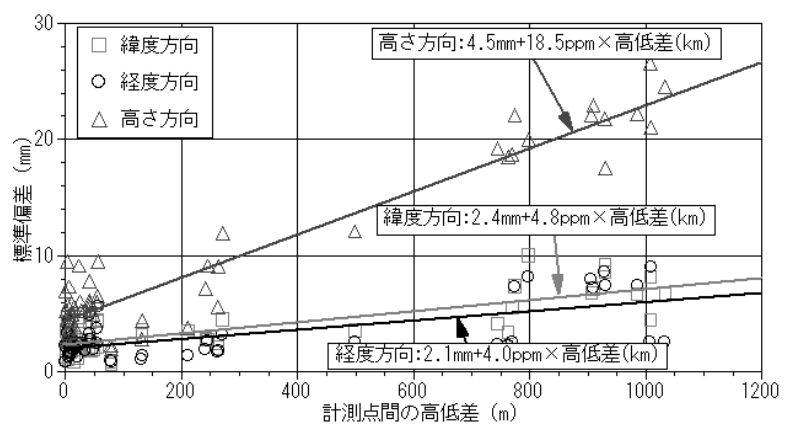

図 12 計測点間の高低差に対する標準偏差

GPS による計測の誤差の要因として, GPS の軌道位置の誤差や 電離層, ならびに大気による電波遅延などが指摘されている ${ }^{12,13)}$ 。 本計測において, 高さ方向に大きく変動のあった 11 月 $15 \sim 16$ 日 は天候の変わり目で, それ以前では量り, または雨, 以後は晴れ であった。高低差が大きいほど, 両計測点において気温, 湿度, 水蒸気量などの気象条件が異なり, さらに, 天候の変化が気象条 件をより大きく変化させ, それが原因で高さ方向に大きな変動が 生じたものと考えられる。もちろん, このことは推察の域を出ず, 明確な原因解明と対策は今後の課題である。

なお, 雨天の期間中は, 山頂が雲あるいは霧に隠れて, 計測点 No.1 およびNo.2 から目視できなかったが, GPS による変位の連 続計測は可能であった。このような特徴をより生かすためにも, 気象条件の補正とともに, 計測点間の高低差の大きい計測条件の 対処法を開発することは重要である。

\section{GPS 変位計測における計測結果の標準偏差}

本章では，3．および 4. の計測結果を含め，これまでに第一， 第二著者らが行った GPS による変位計測結果に基づき, 計測点間 の基線長および高低差をパラメータとして, 緯度, 経度, 高さ方 向の変位計測における計測結果の標準偏差をとりまとめる。

図 11 および図 12 に, 計測点間の基線長および高低差に対する 変位計測結果の標準偏差を示す。図には実測結果に基づき得られ た回帰直線を示している。また, GPS 測量の一般的な標準偏差, 寸なわち, 水平方向 $5 \mathrm{~mm}+1 \mathrm{ppm} \times$ 基線長 $(\mathrm{km})$, 高さ方向 $10 \mathrm{~mm}$ $+2 \mathrm{ppm} \times$ 基線長 $(\mathrm{km})$ も併せて示している (図中破線)。

図 11 から, 本研究による変位計測の計測結果の標準偏差は, 従 来の GPS 測量の標準偏差に比べて小さいことが分かる。基線長が 2,000-3,000 m のところで, 高低差の標準偏差が回帰直線よりやや 大きい計測結果がある。これは後に述べる高低差の影響である。

図 12 から, いずれの成分も高低差の増加とともに標準偏差が大 きくなることが分かる。そしてその傾き ( 緯度, 経度, 高さ方向 に対して，それぞれ， $4.8 \mathrm{ppm}, 4.0 \mathrm{ppm}, 18.5 \mathrm{ppm})$ は，基線長に 対する傾き ( 緯度, 経度, 高さ方向に対して, それぞれ, $1.2 \mathrm{ppm}$,

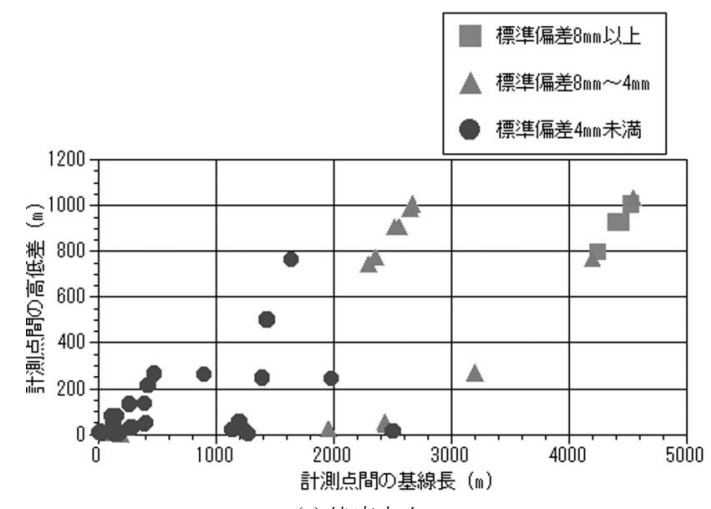

(a) 緯度方向

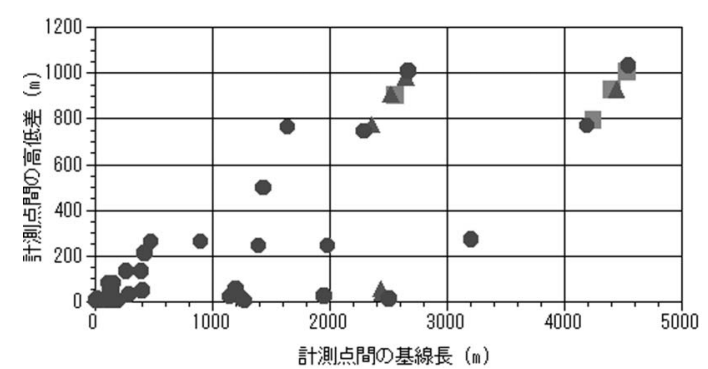

(b) 経度方向

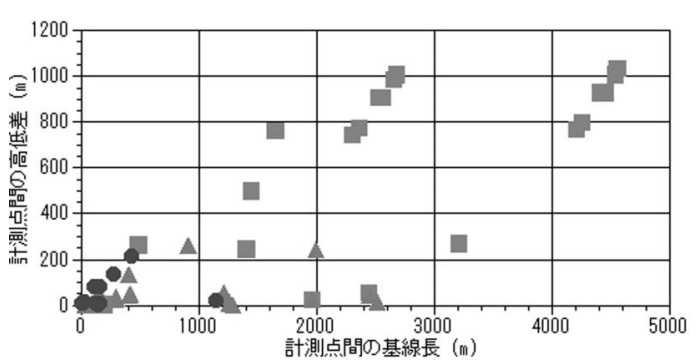

(c) 高さ方向

図 13 計測点間の斜距離および高低差に対する標準偏差

$1.0 \mathrm{ppm}, 4.0 \mathrm{ppm})$ に比べて大きくなっている。特に, 高さ方向の 標準偏差の傾きは, 緯度, 経度方向の標準偏差の傾きに比べてか なり大きい。このことからも, 高低差は変位計測の精度に大きい 影響を及ぼすことが分かる。

以上の計測結果から, GPS による変位計測の計測結果の標準偏 差と, 基線長および高低差に対する関係式は次のようになる。

[ 基線長に対して]

緯度方向 : $1.9 \mathrm{~mm}+1.2 \mathrm{ppm} \times$ 基線長 $(\mathrm{km})$

経度方向 : $1.7 \mathrm{~mm}+1.0 \mathrm{ppm} \times$ 基線長 $(\mathrm{km})$

高さ方向 : $3.8 \mathrm{~mm}+4.0 \mathrm{ppm} \times$ 基線長 $(\mathrm{km})$

[高低差に対して]

緯度方向 : $2.4 \mathrm{~mm}+4.8 \mathrm{ppm} \times$ 高低差 $(\mathrm{km})$

経度方向 : $2.1 \mathrm{~mm}+4.0 \mathrm{ppm} \times$ 高低差 $(\mathrm{km})$

高さ方向 : $4.5 \mathrm{~mm}+18.5 \mathrm{ppm} \times$ 高低差 $(\mathrm{km})$

もちろん, 上記の関係式は著者らの限られた計測結果に対して得 たものであり, より一般性のあるものにするためにはさらにデー タを集積する必要がある。

図 13 に, 図 11 および図 12 に示す標準偏差を, 計測点間の基線 長, および高低差に対して再整理する。ここで, $4 \mathrm{~mm}$ 未満の標準 偏差を○印, $4 \mathrm{~mm}$ 以上 $8 \mathrm{~mm}$ 未満をム印, $8 \mathrm{~mm}$ 以上を印で示 す。図から, 基線長 $1,000 \mathrm{~m}$ 以下, および, 高低差 $300 \mathrm{~m}$ 以下で あれば, 緯度, 経度方向は $4 \mathrm{~mm}$ 未満, 高さ方向は $8 \mathrm{~mm}$ 未満の標 準偏差でおおむ和測できることが分かる。一方, 基線長が 2,000 
$\mathrm{m}$ 以上, および, 高低差が $500 \mathrm{~m}$ 以上となると $4 \mathrm{~mm}$ 未満の標準 偏差の計測が困難となり, 特に, 高さ方向の標準偏差は $8 \mathrm{~mm}$ 以 上となる。

データ数はまだ十分ではないものの, 図 13 から計測点間の基線 長および高低差によって, GPS による変位計測精度の予測をおお まかに行うことができる。なお, 実際の変位計測結果に基づいて, 標準偏差を基線長および高低差との関係を示した図13のような図 は，これまでに見られない本研究の成果である。

\section{6. むすび}

本研究では, 長期間連続計測, および計測点間の高低差の大き い条件下における計測の実例を示し，さらに，これまでの GPS 変 位計測システムの適用結果をとりまとめ, 計測点間の基線長およ び高低差と変位計測における計測結果の標準偏差との関係を示し た。それらをとりまとめると次のようになる。

（1） GPS 変位計測システムによって，1 年を通して安定した連 続計測が長期間可能である。また, 計測結果には, 12 時間お よび 24 時間の周期性がみられるが, 平滑化する時間間隔を 変更することで, 短時間周期の変動を取り除き, 長期間の変 位のトレンドを明瞭に得ることができる。しかし，周期的な 衛星配置, および, 気象条件による周期的な変動を除くため の方法には確立されたものはなく, その開発は今後の課題で ある。

（2）高低差が大きい場合, 特に高さ方向の計測に大きな変動が 生じることがある。その原因として, 高低差による計測点間 の気象条件の差が考えられる。計測点間の気象条件による変 動を取り除く方法の開発は今後の課題である。

（3）実測結果に基づき, 計測点間の基線長, および, 高低差と 変位計測における計測結果との標準偏差の関係を示した。そ の結果,

・基線長 $1,000 \mathrm{~m}$ 以下, および高低差 $300 \mathrm{~m}$ 以下であれば,
緯度, 経度方向は $4 \mathrm{~mm}$ 未満, 高さ方向は $8 \mathrm{~mm}$ 未満の標 準偏差でおおむね計測できる。

・基線長が $2,000 \mathrm{~m}$ 以上, および高低差が $500 \mathrm{~m}$ 以上となる と $4 \mathrm{~mm}$ 未満の標準偏差の計測が困難となり, 特に, 高さ 方向では標準偏差は $8 \mathrm{~mm}$ 以上となる。

ことが示された。

謝辞本研究の一部は, 石灰石鉱業協会研究奨励金 (1998, 2000)を受けて行った。ここに記して謝意を表する。また，4．に おける計測において用いた GPS 受信機は古野電気(株)から提供を 受けた。さらに, 多くの現場計測において協力頂いた関係者各位, 山口大学工学部 故 坂尾和男技官をはじめ, 清水研究室の卒業 生および学生諸君に感謝する。

\section{References}

1) K. Kaneko, Y. Noguchi, K. Soda and M. Hazuku: Sigen-to-Sozai, 112(1996), 915-920.

2) K. Kawahata, T. Ito, M. Tonsho: Sekkaiseki, 297(1999), 20-27.

3) Y. Noda and T. Soda: Sigen-to-Sozai, 113(1997), 408-412.

4) N. Nakamura, Y. Fuji, R. Hazuku and S. Yamazaki : Sekkaiseki, 308(2000), 16-24.

5) H. Kondo, M. E. Cannon, M. E., N. Shimizu and K. Nakagawa: JSCE Journal, 546(1996), No.VI-32, 157-168

6) N. Shimizu, H. Ono, H. Kondo and Y. Mizuta: Shigen-to-Sozai, 112(1996), 283-288

7) N. Shimizu, S. Koyama, H. Ono, K. Miyashita, H. Kondo and Y. Mizuta: Shigen-toSozai, 113(1997), 549-554

8) G. Kitagawa:Jikeiretsu Kaiseki Programming, (Iwanami Shoten, Tokyo, 1993)

9) N. Shimizu, H. Adachi and S. Koyama: Shigen-to-Sozai, 114(1998), 397-402

10) H. Matsuda, H. Adach, Y. Nishimura and N. Shimizu: JSCE Journal, 715(2002), No.III$60,333-343$

11) N. Shimizu, H. Adachi, T. Arai and T. Aizu:Tsuchi-to-Kiso, 48(2000), No.2, 25-27

12) The Geodetic Society of Japan (ed.): Shinteiban GPS, (Japanese Association of Surveyors, 1989)

13) A. Tsuchiya and T. Imaikire: GPS Sokuryo to Kisenkaiseki noTebiki, (Japanese Association of Surveyors, 1994)

14) H. Matsuda, Y. Nishimura, N. Shimizu, T. Arai and T. Aizu:Proc. Annual Meeting of The Japanese Geotechnical Society (2000), pp.2483-2484

15) T. Iwasaki, K. Takechi, A. Takeishi and N. Shimizu: Tsuchi-to-Kiso, 50(2002), No.6, $25-27$

16) H. Matsuda, Y. Nishimura, N. Shimizu, I. Yoshitomi and I. Kon:Proc. The 22nd West Japan Rock Engineering Symposium (West Japan Rock Engineering Society, 2001), pp. $73-76$

17) H. Matsuda, Y. Nishimura and N. Shimizu : Proc. The $56^{\text {th }}$ Annual Meeting of JSCE (Japan Society of Civil Engineers, 2001), CD-ROM, VI150, pp.300-301 